\title{
Correlations between cytokines produced by T cells and clinical-virological characteristics in untreated chronic hepatitis B patients
}

Yurong Gu ${ }^{1+}$, Yifan Lian ${ }^{2 \dagger}$, Lin Gu${ }^{2}$, Lubiao Chen ${ }^{1}$, Xiaoyan $\mathrm{Li}^{1}$, Liang Zhou' ${ }^{1}$, Yanlin Huang ${ }^{1}$, Jialiang Wang ${ }^{2}$ and Yuehua Huang ${ }^{1,2^{*}}$ (D)

\begin{abstract}
Background: Hepatitis B virus (HBV) replicates non-cytopathically in the hepatocytes and HBV-related diseases are caused by immune-mediated inflammatory events. This study aimed to identify the relationship between clinicalvirological characteristics and immunity in untreated chronic hepatitis B (CHB) patients.

Methods: A total of 209 CHB patients were categorized into immune tolerant (IT, $n=17)$, inactive carrier (IC, $n=20)$, immune active (IA, $n=120)$, and gray zone $(G Z, n=72)$ phases. The quantitative hepatitis $B$ surface antigen (qHBsAg), hepatitis B e antigen ( $\mathrm{HBeAg})$, anti-HBeAg (HBeAb), HBV genotype, viral mutant and frequencies of interleukin (IL)-4, IL-17, IL-10 and interferon-gamma (IFN- $\gamma$ ) produced by $C D 4^{+}$and $C D 8^{+} T$ cells were tested. We also correlated these cytokines with clinical-virological characteristics using a linear regression model.

Results: $\mathrm{CD} 8^{+} \mathrm{T}$ cells frequency were significantly decreased in IT patients. Levels of $\mathrm{CD} 4^{+} \mathrm{T}$ cells $\mathrm{IL}-4^{+}$or $\mathrm{LL}-10^{+}$were strongly negatively associated with qHBsAg titers. The frequency of IFN- $\gamma$ produced by $\mathrm{CD}^{+}$and $\mathrm{CD} 8^{+} \mathrm{T}$ cells showed significant positive association with age and alanine aminotransferase (ALT) level, while that had negative association with qHBsAg titers. Additionally, the ratios of mutations in the HBV precore (PC) stop codon and basal core promoter (BCP) and the combined mutations were $32.5,27.2$, and $11.3 \%$, respectively. The frequency of CD4 ${ }^{+} \mathrm{T}$ cells $\mathrm{IL}-17^{+}$was higher in patients with a PC mutation than that in patients carrying a wild-type sequence. Finally, little associations among $T$ cell derived IL-4, IL-10, IL-17, and IFN- $\gamma$ was observed in the current untreated CHB cohort.
\end{abstract}

Conclusions: Several components of the immune system were correlated with HBV factors that influence an inflammatory process during CHB. Of particular relevance are the significant associations of between $\mathrm{CD} 4^{+} \mathrm{T}$ cells IL-4 ${ }^{+}$ and qHBsAg level, and between CD4 ${ }^{+} \mathrm{T}$ cells $\mathrm{IL}-17^{+}$and the presence of a mutation in PC.

Keywords: Chronic hepatitis B (CHB), Cytokines, Linear regression analysis

\footnotetext{
* Correspondence: huangyh53@mail.sysu.edu.cn

†Yurong Gu and Yifan Lian contributed equally to this work.

'Department of Infectious Diseases, The Third Affiliated Hospital of Sun

Yat-sen University, 600 Tian He Rd., Guangzhou 510630, China

${ }^{2}$ Guangdong Provincial Key Laboratory of Liver Disease Research, The Third

Affiliated Hospital of Sun Yat-sen University, Guangzhou, China
}

(c) The Author(s). 2019 Open Access This article is distributed under the terms of the Creative Commons Attribution 4.0 International License (http://creativecommons.org/licenses/by/4.0/), which permits unrestricted use, distribution, and reproduction in any medium, provided you give appropriate credit to the original author(s) and the source, provide a link to the Creative Commons license, and indicate if changes were made. The Creative Commons Public Domain Dedication waiver (http://creativecommons.org/publicdomain/zero/1.0/) applies to the data made available in this article, unless otherwise stated. 


\section{Background}

Although a prophylactic vaccine and effective antiviral therapies are available, chronic hepatitis $\mathrm{B}(\mathrm{CHB})$ remains a significant global health threat, affecting more than 240 million people [1]. The Asian-Pacific region is a hyper-endemic area of chronic hepatitis, and a majority of hepatitis B virus (HBV) infections eventually progress to end-stage liver diseases including cirrhosis, as well as to hepatocellular carcinoma (HCC) [2].

HBV belongs to Hepadnaviridae, a family of enveloped viruses with an incomplete double-stranded DNA genome of $3.2 \mathrm{~kb}$ [3]. The quantitative level of serum hepatitis B surface antigen (HBsAg) has been suggested to serve as an indicator of a response to antiviral treatment $[4,5]$. However, the serum level of HBsAg is dynamic, and its correlation with the level of serum HBV DNA appears to change in different phases of the natural history of chronic hepatitis B [6, 7]. According to current practice guidelines, the disease status of $\mathrm{CHB}$ patients can be grouped into four phases, as indicated by the level of hepatitis $\mathrm{B}$ e antigen (HBeAg), serum ALT and HBV DNA: immune tolerant (IT), immune active (IA); inactive carrier (IC); gray zones (GZ) [8].

In addition to HBV antigen titers and viral load, the HBV genotype and virus mutations have been well documented as risk predictors of cirrhosis and HCC in $\mathrm{CHB}$ patients [9-12]. Based on sequence divergence $>8 \%$ for the entire HBV genome, 10 genotypes (A-J) have been identified to date [12]. HBV genotypes have distinct geographical distributions worldwide and differ with regard to clinical diseases, prognosis, and response to interferon treatment [13, 14]. In addition, mutations in different parts of the viral genome occur due to the stress from humoral and cell-mediated immunities. Core promoter mutants are not only associated with an increased risk of HCC development but also have a direct relationship with poor survival in postoperative HCC patients [15, 16]. Another common mutation, G1896A (which changes a TGG tryptophan codon to a TAG stop codon), in the precore (PC) region of the virus has been identified as being related to $\mathrm{HBeAg}$ seroconversion. Patients carrying this PC mutation do not express $\mathrm{HBeAg}$ and still suffer from severe liver disease $[17,18]$.

It is clear that HBV replicates non-cytopathically in the hepatocytes and that virus-related diseases are caused by chronic immune-mediated inflammatory events [19]. During the course of liver damage, adaptive immune cells are crucially involved in the pathogenesis of hepatic inflammation, with $\mathrm{T}$ cells playing particularly important roles in antiviral defense [20-22]. $\mathrm{T}$ lymphocyte activity is largely dependent on the differentiation of naïve $\mathrm{T}$ cells into $\mathrm{T}$ helper cells or effector $\mathrm{T}$ cell subsets via the release of cytokines [23]. It is well documented both in vitro and in vivo that antiviral $\mathrm{T}$ cell function is more efficient in patients in whom infection can be controlled either partially, such as for inactive HBsAg carriers with low levels of virus replication, or completely, such as for patients who achieve HBsAg loss either spontaneously or after longitudinal antiviral therapy [24, 25]. Moreover chronic inflammation alters not only the access and function of HBV-specific $\mathrm{T}$ cells in the liver parenchyma, but also the ability of secreted cytokines to activate antiviral mechanisms [26, 27]. Persistent exposure of $\mathrm{T}$ cells to $\mathrm{HBV}$ antigens is important for maintaining depressed $\mathrm{T}$ cell functionality [28].

Although previous studies have demonstrated the roles of $\mathrm{T}$ cell immune responses and viral factors in the progression of CHB [29], few studies have evaluated the associations of different subpopulations of $\mathrm{T}$ cells and their cytokines with clinical-virological factors using a logistic model adjusted for age, sex, HBV parameters, liver fibrosis and inflammation in a treatment naïve $\mathrm{CHB}$ cohort. Therefore, in this study, we measured $\mathrm{T}$ cell subsets as well as their cytokines, including $\mathrm{CD}^{+}$and $\mathrm{CD}^{+} \mathrm{T}$ cells, effector cytokines IFN- $\gamma$ and interleukin (IL)-17, and Th2 cytokine IL-4 and immunomodulatory cytokine IL-10, in naïve CHB patients at different disease phases. Correlations between $\mathrm{T}$ cell-produced cytokines and clinical-virological characteristics was also analyzed.

\section{Methods}

\section{Patients}

Consecutive adult patients with $\mathrm{CHB}$ infection observed in the dedicated viral hepatitis clinic of The Third Affiliated Hospital of Sun Yat-sen University between July 2015 and July 2016 were recruited. Patients were excluded for the following reasons: receiving antiviral treatment (IFN- $\alpha$ or nucleoside analogs) within the previous 6 months; patients with human immunodeficiency virus (HIV), hepatitis $C$ virus, or hepatitis D virus coinfection; and patients with end-stage liver insufficiency, autoimmune disorders, immunosuppressive treatment, cirrhosis, and malignancies. Written informed consent was obtained from all patients. The study was approved by the Institutional Review Board of the Sun Yat-sen University, and it conforms with the provisions of the Declaration of Helsinki.

Of the 244 individuals eligible for participation in this study, 15 were excluded because of missing data, leaving 229 patients available for analysis. The classification and denomination of $\mathrm{CHB}$ patients in this study was based exclusively on serological and biochemical parameters, in 
accordance with published international treatment guidelines, as follows: (1) IT phase - normal alanine aminotransferase (ALT) level, elevated HBV DNA, typically $>1$ million IU/mL, HBeAg positivity; (2) IA phase - elevated ALT level, HBeAg positivity, HBV DNA $>20,000 \mathrm{IU} / \mathrm{mL}$, or HBeAg negativity HBV DNA > $2000 \mathrm{IU} / \mathrm{mL}$; (3) IC phase normal ALT level, anti-HBsAg (HBeAb) positivity, low HBV DNA level; (4) GZ phase - ALT and HBV DNA levels do not falling into the same above traditionally characterized phases [8]. In addition, blood was also obtained from age and sex matched non-HBV infected healthy controls ( $n=17, p=0.77$ and 0.98 for age and sex respectively, compared with $\mathrm{CHB}$ patients). Healthy controls were recruited from Physical Examination Center in our hospital. Information on the demographics (age range, sex distribution), HBV markers (HBV DNA, HBeAg, HBsAg, HBeAb, anti-HBsAg [HBsAb]), ALT, HBV genotypes, and HBV mutants (PC and basal core promoter [BCP] mutants) of $\mathrm{CHB}$ patients and healthy controls is listed in Table 1.

\section{Cell-surface and cytokines staining and flow cytometry analysis}

Peripheral blood mononuclear cells (PBMCs) were isolated from fresh blood samples using Ficoll density gradients according to the manufacturer's instructions. The isolated PBMCs were stained for surface markers, fixed, permeabilized with IntraPreReagent (Beckman Coulter, Fullerton, CA), and further stained with antibodies directed against intracellular markers. Leukocytes were stimulated with Leukocyte Activation Cocktail (BD Pharmingen, San Diego, CA) at $37^{\circ} \mathrm{C}$ for $4 \mathrm{~h}$ prior to intracellular staining using the manufacturer's staining protocol. Anti-human monoclonal antibodies (mAbs) against PE-CF594-CD3, APC-CD4, V450-CD8, FITC-IFN- $\gamma$, PE-IL-4, APC-IL-17A, and APC-IL-10 with corresponding isotype-matched controls were purchased from BD Biosciences (San Jose, CA, USA). Data were acquired using a Gallios instrument (Beckman Coulter, Brea, CA) and analyzed with FlowJo software (Ashland, OR).

Table 1 Clinical-virological characteristics of patients included in the study

\begin{tabular}{|c|c|c|c|c|c|c|}
\hline Characteristics & $\mathrm{IT}(n=17)$ & $\mathrm{A}(n=120)$ & $I C(n=20)$ & $\mathrm{GZ}(n=72)$ & $\mathrm{HC}(n=17)$ & $P$ value \\
\hline Age, years, median (quartile) & $25(24,26)$ & $29(25,33.25)$ & $32(28.75,37)$ & $31.5(26,38.25)$ & $27(25.5,36)$ & $<0.001$ \\
\hline Gender & & & & & & 0.238 \\
\hline Male, $n$ (\%) & $12(70.6)$ & $77(64.2)$ & $17(85)$ & $55(76.4)$ & 12 (70.6) & \\
\hline Female, $n(\%)$ & $5(29.4)$ & $43(35.8)$ & $3(15)$ & $17(23.6)$ & $5(29.4)$ & \\
\hline ALT, U/L, median (quartile) & $20.6(18.3,22.4)$ & $20.8(19.1,22.5)$ & $22.3(21.6,23.8)$ & $21.484(19.8,23.4)$ & $16(12.5,22.0))$ & $<0.001$ \\
\hline Fibroscan, Kpa median (quartile) & $4.9(4.2,5.4)$ & $5.3(4.3,6.5)$ & $4.4(4.0,5.3)$ & $4.8(4.4,5.4)$ & $4.6(4.0 \sim 5.1)$ & 0.016 \\
\hline HBV DNA, Log IU/ml, median (quartile) & $8.2(8.2,8.2)$ & $7.7(5.0,8.2)$ & $2.2(1.6,3.1)$ & $3.3(2.1,4.3)$ & & $<0.001$ \\
\hline HBeAg status & & & & & & $<0.001$ \\
\hline Negative, $n(\%)$ & $0(0)$ & $41(34)$ & $20(100)$ & $62(86)$ & & \\
\hline Positive, $n(\%)$ & $17(100)$ & $78(65)$ & $0(0)$ & $10(14)$ & & \\
\hline Missing, $n(\%)$ & $0(0)$ & $1(1)$ & $0(0)$ & $0(0)$ & & \\
\hline HBeAb status & & & & & & $<0.001$ \\
\hline Negative, $n$ (\%) & $17(100)$ & $70(58.3)$ & $1(5)$ & $13(18.1)$ & & \\
\hline Positive, $n(\%)$ & $0(0)$ & $47(39.2)$ & $19(95)$ & $59(81.9)$ & & \\
\hline Missing, $n(\%)$ & $0(0)$ & $3(2.5)$ & $0(0)$ & $0(0)$ & & \\
\hline qHBsAg, Log IU/ml, median (quartile) & $4.6(4.5,4.7)$ & $4.0(3.3,4.7)$ & $2.9(2.0,3.2)$ & $3.2(2.3,3.6)$ & & $<0.001$ \\
\hline HBsAb status & & & & & & $<0.001$ \\
\hline Negative, $n(\%)$ & $15(88)$ & $106(88)$ & $20(100)$ & $67(93)$ & & \\
\hline Positive, $n$ (\%) & $2(12)$ & $14(12)$ & $0(0)$ & $5(7)$ & & \\
\hline HBV genotype & & & & & & $<0.001$ \\
\hline$C, n(\%)$ & $2(12)$ & $30(25)$ & $3(15)$ & $15(21)$ & & \\
\hline$B, n(\%)$ & $12(71)$ & $74(62)$ & $8(40)$ & $27(38)$ & & \\
\hline Other, $n(\%)$ & $1(6)$ & $10(8)$ & $9(45)$ & $29(40)$ & & \\
\hline Missing, $n(\%)$ & $2(11)$ & $6(5)$ & $0(0)$ & $1(1)$ & & \\
\hline
\end{tabular}

HBV genotype: Other included $C+D, B+D, B+C, D$, and not detected

IT, immune tolerant; IA, immune active; IC, inactive carrier; GZ, gray zones; ALT, alanine aminotransferase; HBeAb, antibody to HBV e antigen; HBeAg, HBV e antigen; HBsAb: antibody to hepatitis B surface antigen; HBsAg, hepatitis B surface antigen; PC: precore; BCP: basal core promoter 


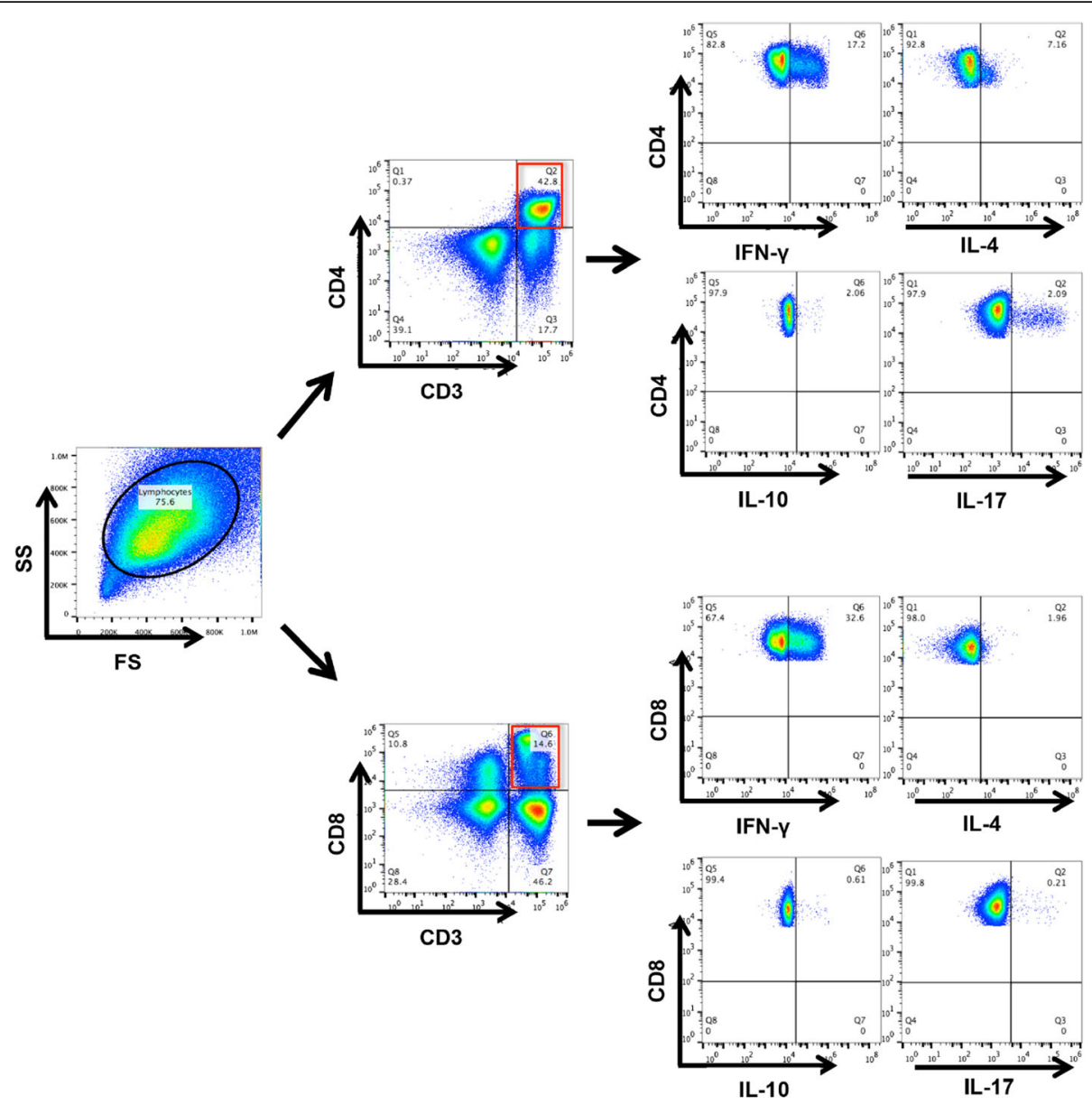

Fig. 1 Gating strategy for IL-4, IL-10, IFN-y, IL-17 produced by CD4 $4^{+}$and CD8 ${ }^{+} T$ cells. T cells were derived from total live PBMCs gated by forward and side scatter followed by single-cell gating using width and height parameters. $\mathrm{CD} 4^{+}$and $\mathrm{CD} 8^{+} \mathrm{T}$ cells were defined by the co-expression of

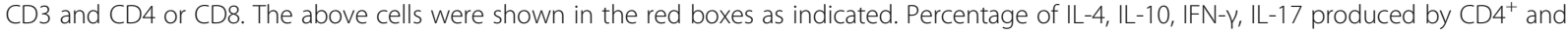
$\mathrm{CD}^{+} \mathrm{T}$ cells were further calculated according to the fluorescence of each cytokine antibody

\section{Clinical and serological parameters}

Upon recruitment, patient serum was tested for $\mathrm{HBsAb}$, $\mathrm{HBeAb}, \mathrm{HBeAg}$ using commercial kits (Abbott Laboratories, North Chicago, IL). Quantitative HBsAg (qHBsAg) (dynamic range from 0.05 to $52,000 \mathrm{IU} / \mathrm{ml}$ ) and HBsAb levels were measured with the Elecsys HBsAg II Quant reagent kits (Roche Diagnostics, Indianapolis, IN) according to the manufacturer's instructions. Serum HBV DNA level was measured by Roche COBAS Ampliprep/COBAS TaqMan HBV Test v2.0 (dynamic range from 20 to $1.7 \mathrm{E}+08 \mathrm{IU} / \mathrm{mL}$, Roche Molecular Diagnostics, Branchburg, NJ). Level of fibrosis was defined by liver stiffness measurement (Fibroscan, Echosens, Paris, France). Genotyping of HBV was carried out by polymerase chain reaction-restriction fragment length polymorphism of the surface gene of HBV as previously described [11, 30]. Briefly, the extracted DNA was amplified for the fragment of the
HBV genome between nucleotide positions 256 and 796. The polymerase chain reaction products were subsequently treated with restriction enzymes. After incubation, the samples were run on a $3 \%$ agarose gel and stained by ethidium bromide. Six genotypes (A-F) of $\mathrm{HBV}$ were identified by the restriction patterns of DNA fragments. Unclassified genotype was defined as an unpredictable or atypical restriction pattern.

\section{Statistical analysis}

We compared two patient groups using the Mann-Whitney test for continuous variables and the $\chi^{2}$ test for categorical variables. We explored the association between two continuous variables using a linear regression model, Pearson correlation or Spearman correlation. All other statistical tests were performed using $\mathrm{R}$ software version 3.2.2. Statistical significance was set to 0.05 . 


\section{Results}

Peripheral blood $\mathrm{T}$ cell subsets and cytokine profiles in different disease phases of CHB patients

To investigate $\mathrm{T}$ cell immunity in the current untreated patient cohort, we characterized the frequencies of $\mathrm{T}$ cell subsets and their secreted cytokines in $229 \mathrm{CHB}$ patients in different phases of the disease. Gating strategy of flow cytometry for cytokines produced by $\mathrm{CD}^{+}$and $\mathrm{CD}^{+} \mathrm{T}$ cells is shown in Fig. 1. The clinical features of the patient cohort studied are shown in Table 1 . We first analysed proportions of $\mathrm{CD}_{4}^{+}$and $\mathrm{CD}^{+} \mathrm{T}$ cells and compared these $\mathrm{T}$ cell profiles among different patient groups. No statistically significant differences in the distribution of $\mathrm{CD}^{+}{ }^{+} \mathrm{T}$ cells were observed among the IA, IT, IC and GZ groups or healthy control (Fig. 2). In contrast, the frequency of $\mathrm{CD}^{+} \mathrm{T}$ cells was significantly increased in patients in the IA phase compared to those in the IT phase $(P=0.02)$, suggesting higher cytotoxic activity in patients with increased liver inflammation.

The frequencies of $\mathrm{T}$ cell subsets producing effector/ inflammatory cytokines (IFN- $\gamma$ and IL-17), $\mathrm{T}$ helper cytokine (IL-4) and immunomodulatory cytokine (IL-10) were also analyzed. Compared to the levels observed in other patient groups, a significant decrease in IFN- $\gamma$ level was detected in both $\mathrm{CD}^{+}$and $\mathrm{CD} 8^{+} \mathrm{T}$ cells from IT patients. Moreover, discrepancies in the frequencies of IL- 4 and IL-10 by T-cell subset in patients at different disease phases were also observed. Patients in the IC and IA phases exhibited significantly higher levels of IL-4 and IL-10 produced by CD4 ${ }^{+} \mathrm{T}$ cells, respectively, in comparison to the levels observed in IT patients. An increase in IL-4 from $\mathrm{CD}^{+} \mathrm{T}$ cells was also observed in GZ patients when compared to patients of the IA and IT phases (Fig. 3). No variation in IL-17 expression was found for any $\mathrm{T}$ cell subset among the patient groups.

Taken together, these data demonstrate that the lowest frequency of $\mathrm{T}$ cells and their cytokine functions were in
IT patients. However, no divergent behaviours of $\mathrm{T}$ cell and cytokine profiles, as defined by three clinical-virological parameters (ALT, HBV DNA, HBeAg), were observed among other patient groups. We therefore included patient demographics, HBV markers, ALT, and liver fibroscan values to explore correlations between cellular immunity and HBV status using linear regression.

\section{Correlation of T cell-producing Th2 cytokine and immunomodulatory cytokine to viral factors}

A linear regression model was used to examine associations of Th2 cytokine (IL-4) and immunomodulatory cytokine IL-10 to clinical-virological factors in this untreated $\mathrm{CHB}$ cohort. Univariate analysis revealed that higher levels of HBsAg, HBeAg and HBV DNA were significantly associated with decreased frequencies of $\mathrm{CD} 4^{+} \mathrm{T}$ cells IL- $4^{+}(P$ $=0.005,0.012$, and 0.01 for HBsAg, HBeAg and HBV DNA, respectively). Similar results were found regarding the correlation between above-mentioned HBV factors and $\mathrm{CD}^{+}{ }^{+}$cells $\mathrm{IL}^{+}(P=0.004,0.005$, and 0.000 for HBsAg, HBeAg and HBV DNA, respectively). Moreover, increased $\mathrm{HBeAb}$ titers and the presence of $\mathrm{PC}$ mutation were correlated with higher IL-4 secreted by $\mathrm{CD}^{+}$and $\mathrm{CD} 8^{+} \mathrm{T}$ cells, respectively $(P=0.026,0.037$, for the relationship between $\mathrm{HBeAb}$ and $\mathrm{CD}_{4}^{+} \mathrm{T}$ cells IL-4 $4^{+}$, and between PC mutation and $\mathrm{CD}^{+} \mathrm{T}$ cells $\mathrm{IL}-4^{+}$, respectively). Multivariate analysis after adjusting for other confounding factors showed that HBsAg and HBV DNA remained significantly negatively correlated to IL- 4 secreted by $\mathrm{CD}^{+}$and $\mathrm{CD}^{+} \mathrm{T}$ cells, respectively $(P=0.005,0.000$, for the relationship between HBsAg and $\mathrm{CD}_{4}^{+} \mathrm{T}$ cells $\mathrm{IL}-4^{+}$, and between HBV DNA and $\mathrm{CD}^{+}{ }^{+}$cells $\mathrm{IL}-4^{+}$, respectively, Table 2 ).

Similarly, linear regression was used to examine the association between IL-10 by $\mathrm{T}$ cell subsets and virological factors. Increased HBsAg levels were significantly associated with lower expression of $\mathrm{CD}^{+}{ }^{+} \mathrm{T}$ cells $\mathrm{IL}-10^{+}$,
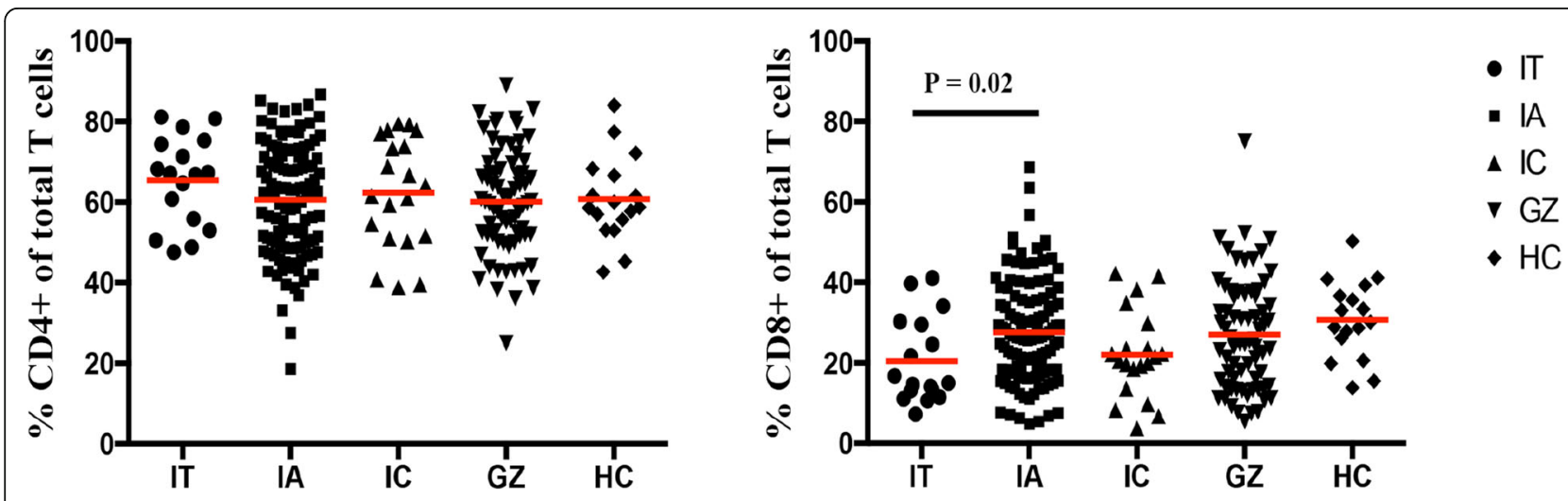

Fig. 2 Frequency of $C D 4^{+}$and $C D 8^{+}$T cells in IT $(n=17), I A(n=120)$, IC $(n=20)$ and $G Z(n=72)$ phases of naïve CHB patients, and of healthy control $(n=17)$. The levels were compared among these patients in different phases, and those of healthy controls. (IT, immune tolerant; IA, immune active; IC, inactive carrier; $G Z$, gray zones) 
as indicated by multivariate analysis $(P=0.033)$. Conversely, IL-10 produced by both $\mathrm{T}$ cell subsets exhibited significantly positive correlations with HBsAb titers $(P=0.014$, 0.032, for the relationship between $\mathrm{HBsAb}$ and $\mathrm{CD} 4^{+} \mathrm{T}$ cells $\mathrm{IL}-10^{+}$, and between $\mathrm{HBsAb}$ and $\mathrm{CD}^{+}{ }^{+} \mathrm{T}$ cells $\mathrm{IL}-10^{+}$, respectively, Table 2).

Taken together, these findings indicated an association of Th2 cytokine and immunomodulatory cytokine to HBV protein status, viral replication, and mutation.

\section{Effector cytokine responses associated with clinical virology and liver inflammation}

The linear regression model demonstrated that older age, higher ALT level, and lower HBsAg titer were significantly correlated with increased $\mathrm{CD}^{+}{ }^{+} \mathrm{T}$ cells IFN- $\gamma^{+}(P=0.003,0.000$ and 0.029 , for the relationship between age, ALT or HBsAg, respectively, and $\mathrm{CD} 4^{+} \mathrm{T}$ cells IFN $\left.-\gamma^{+}\right) . \mathrm{CD}^{+} \mathrm{T}$ cells IFN $-\gamma^{+}$was also observed to be correlated with age and levels of ALT and HBsAg $(P=0.004,0.000$ and 0.004 , for the relationship between age, ALT or HBsAg, respectively, and $\mathrm{CD}^{+} \mathrm{T}$ cells $\mathrm{IFN}-\gamma^{+}$). Similar results were observed after adjusting for other confounding factors (Table 3). There was also a statistically significant positive relationship between the frequency of $\mathrm{CD} 4^{+}$ $\mathrm{T}$ cells IFN $-\gamma^{+}$and the fibroscan value $(P=0.005)$. However, multivariate analysis indicated a lack of a statistically significant correlation.

In addition to IFN- $\gamma$, data from multivariate analysis demonstrated a correlation between reduced levels of cytokine IL-17 and the presence of PC and BCP mutation of HBV genome $(P=0.037$, Table 3$)$. However, this phenomenon was only observed for the relationship between $\mathrm{PC}$ mutation and $\mathrm{CD} 4^{+} \mathrm{T}$ cells $\mathrm{IL}-17^{+}$and not $\mathrm{CD}^{+} \mathrm{T}$ cells $\mathrm{IL}-17^{+}$.

\section{Associations among immunological responses}

Because individual $\mathrm{T}$ cell cytokines were found to be correlated with one or more clinical-virological parameters in this untreated $\mathrm{CHB}$ cohort, we further investigated associations among frequencies of IL-4, IL-10, IL-17, and IFN- $\gamma$ by $\mathrm{T}$ cell subsets. As expected, there was a significant association between $\mathrm{CD} 4^{+} \mathrm{T}$ cells IL- $4^{+}$ and $\mathrm{CD}^{+} \mathrm{T}^{-}$cells IL- $4^{+}(\mathrm{r}=0.54, P<0.05)$. Similar findings were observed for relationships between $\mathrm{CD} 4^{+} \mathrm{T}$ cells $\mathrm{IL}-10^{+}$and $\mathrm{CD}^{+} \mathrm{T}$ cells $\mathrm{IL}-10^{+}(\mathrm{r}=0.78)$, and $\mathrm{CD}^{+}{ }^{+} \mathrm{T}$ cells $\mathrm{IL}-17^{+}$and $\mathrm{CD} 8^{+} \mathrm{T}$ cells $\mathrm{IL}^{-}-17^{+}(\mathrm{r}=0.6)$, and $\mathrm{CD} 4^{+} \mathrm{T}$ cells IFN $-\gamma^{+}$and $\mathrm{CD} 8^{+} \mathrm{T}$ cells IFN $-\gamma^{+}(\mathrm{r}=0.77)$, respectively. Notably, although statistically significant associations were observed among these cytokines by $\mathrm{CD}^{+}$or $\mathrm{CD}^{+} \mathrm{T}$ cells, the correlation coefficients were small, suggesting weak autocorrelations among these cytokines, which indicated that IL-4, IL-10, IL-17, and IFN- $\gamma$ were nearly independently correlated with $\mathrm{HBV}$ factors (Fig. 4).

\section{Discussion}

This study demonstrates associations between several effector or helper cytokines produced by $\mathrm{T}$ cell subsets and the levels of HBV markers and liver inflammation in 229 treatment-naïv $\mathrm{CHB}$ patients. In particular, the frequencies of $\mathrm{CD}^{+} \mathrm{T}$ cells IL- $4^{+}$or $\mathrm{IL}-10^{+}$were strongly associated with HBsAg or HBsAb. Levels of IFN- $\gamma$ secreted by $\mathrm{CD}^{+}$and $\mathrm{CD}^{+} \mathrm{T}$ cells were also significantly associated with older age and increased ALT and HBsAg. In addition, the frequency of $\mathrm{CD} 4^{+} \mathrm{T}$ cells $\mathrm{IL}-17^{+}$was significantly higher in patients with $\mathrm{PC}$ mutation than those with wild-type PC sequences.

In the natural course of HBV infection, HBsAg loss occurs at an annual rate of $0.5-2.3 \%$ [31-33]. Quantitative $\mathrm{HBsAg}$ levels can predict the seroclearance of $\mathrm{HBsAg}$ in $\mathrm{HBeAg}$ seroconverters or $\mathrm{HBeAg}$-seronegative

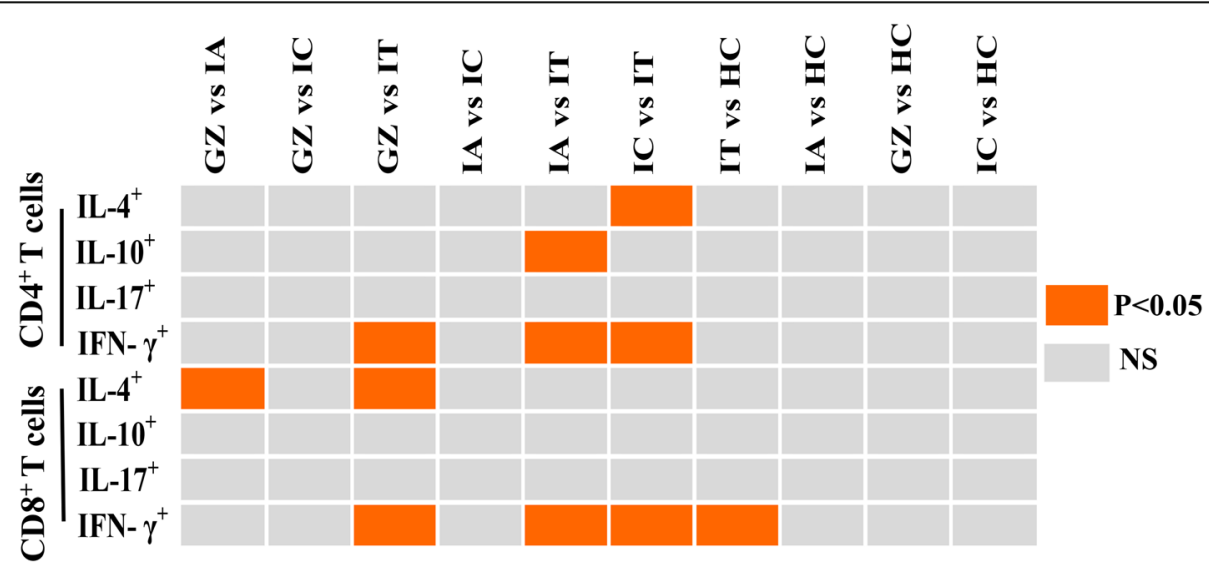

Fig. 3 Comparison of cytokines IL-4, IL-10, IFN- $\gamma$, IL-17 produced by CD4 ${ }^{+}$and CD8 $8^{+} T$ cells among naïve CHB patients in IT, IA, IC, GZ phases and healthy control. Differences between multiple groups had been evaluated by Wilcoxon rank sum test. $P<0.05$ was colored in red. NS, not significant. (IT, immune tolerant; IA, immune active; IC, inactive carrier; GZ, gray zones) 


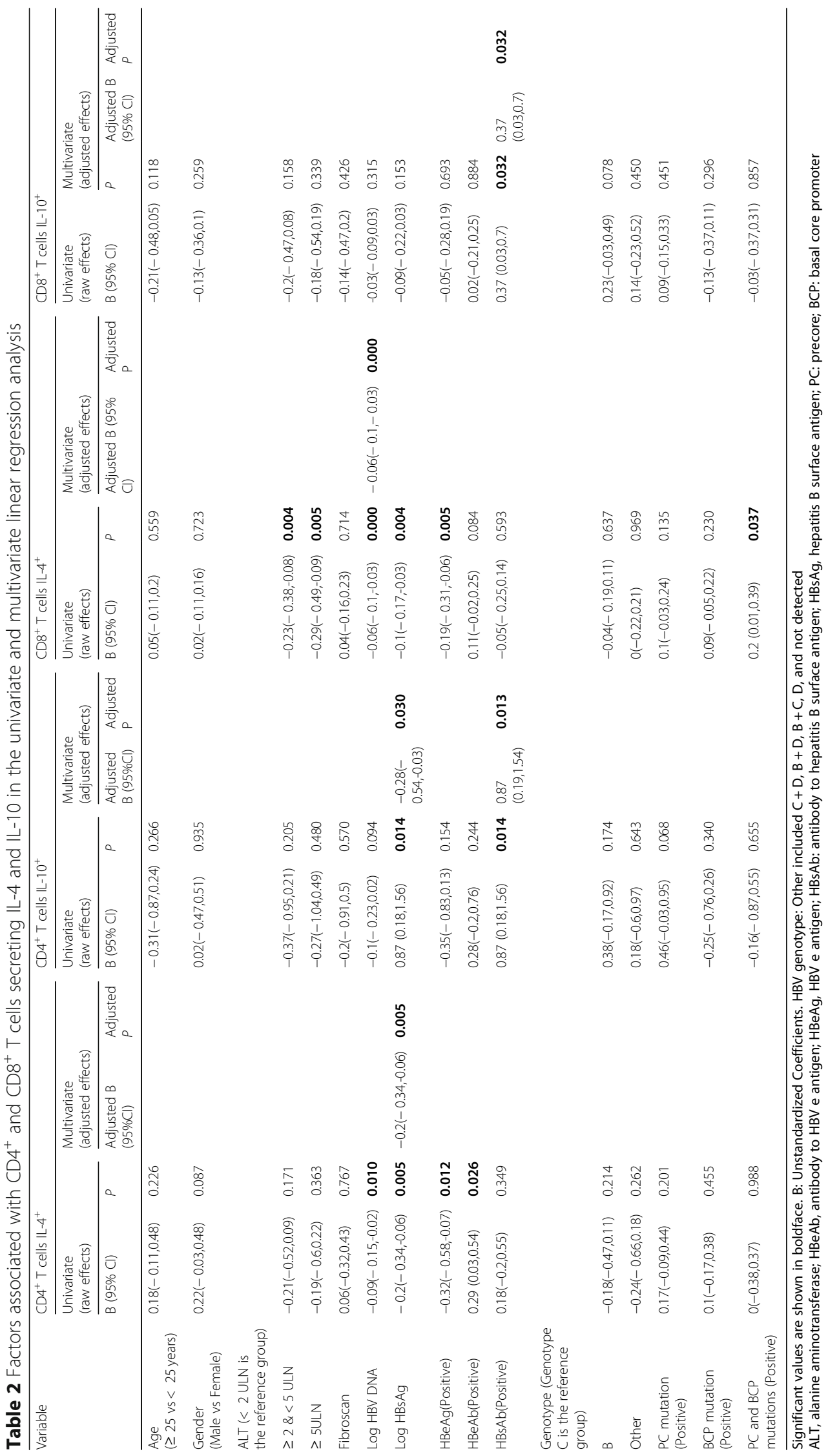




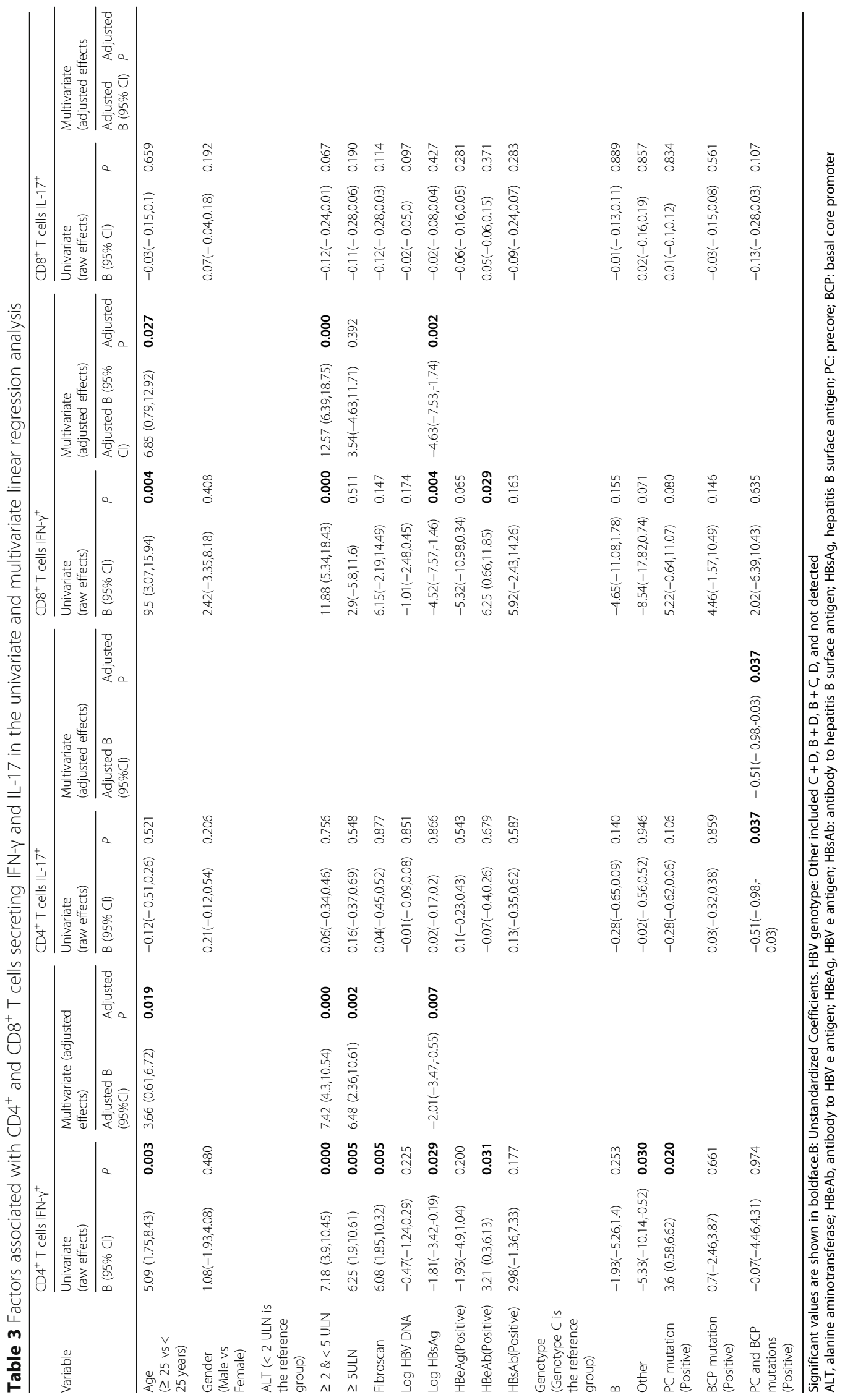




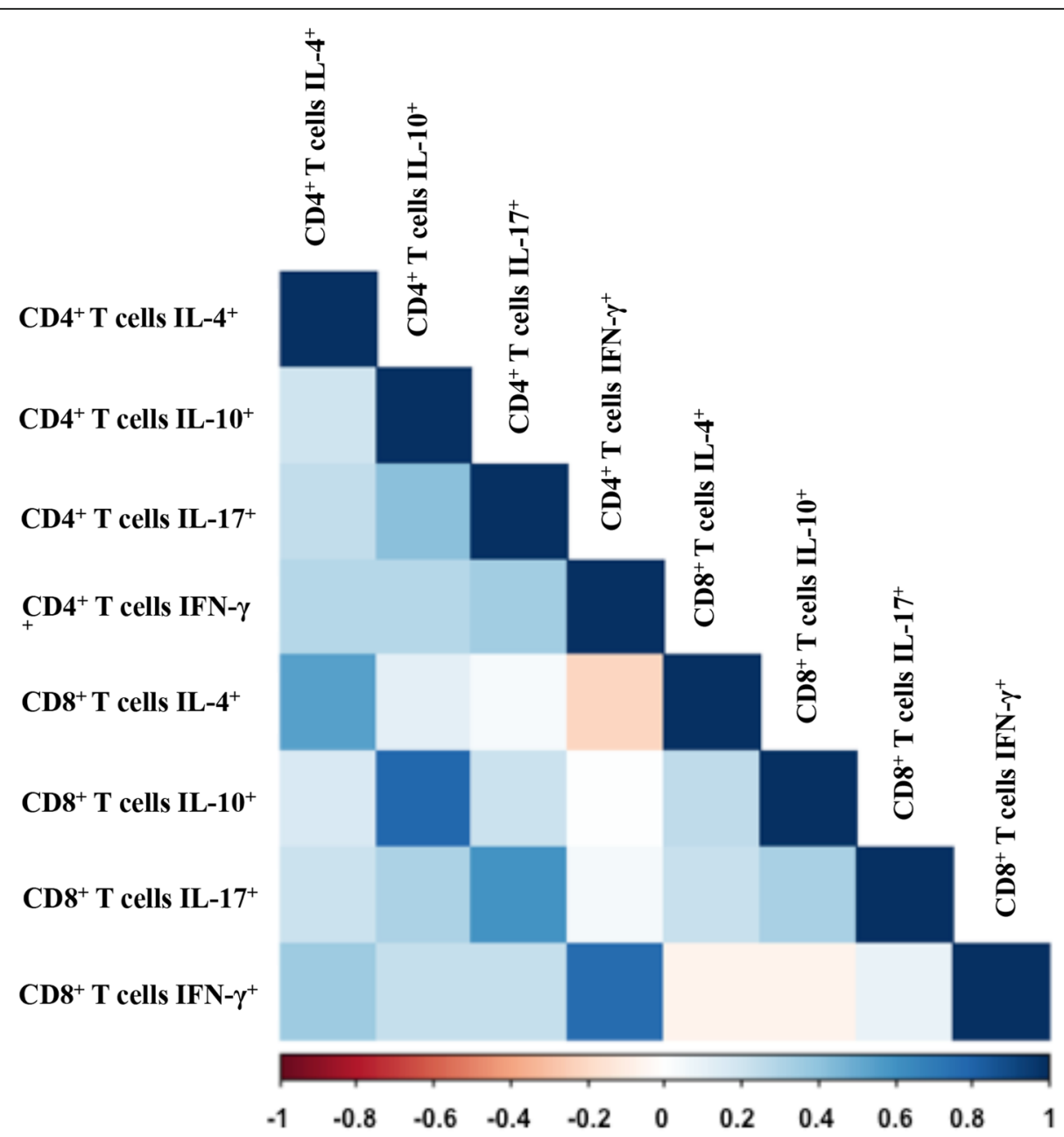

Fig. 4 Correlations among IL-4, IL-10, IFN- $\gamma$ and IL-17 produced by CD4 ${ }^{+}$and $C D 8^{+} T$ cells measured by Spearman correlation. $P<0.05$ was colored, and pseudocolours indicate correlation levels from negative $(-1)$ to positive (1), ranging from a weak (white) to strong (red or blue) association strength

patients with low viral loads [34]. For patients with low HBV DNA, the risk of HCC development is considered in an HBsAg titer-dependent manner [35]. By Integrating the characteristics of cellular immunity and the virus, we observed significant associations for both IL-4 and IFN- $\gamma$ with the HBsAg levels, despite the counteracted characteristics between them. IL-4 is a multifunctional pleiotropic cytokine that plays important roles as a mediator and modulator of inflammatory immunity [36]. Inconsistent with previous reports that IL-4 is positively correlated with serum viral load and ALT to exert its suppressive effect on $\mathrm{T}$ helper cytokine function by promoting neutrophil survival and hepatitis [37], the observed contrasting significant correlations of IL-4 with $\mathrm{HBeAg}$ and HBeAb in the current study primarily demonstrates the essential regulation of Th2 cell response during $\mathrm{HBeAg}$ seroconversion. These divergent signatures of IL-4 in CHB may be due to gene polymorphisms [36], and it might need further study to investigate the relationship between gene polymorphisms and $\mathrm{HBeAg}$ seroconversion or antiviral efficacy. In addition, the significantly positive correlations between IFN- $\gamma$ and age or ALT represent the inflammatory features of IFN- $\gamma$ [38-40].

HBV mutations might play a pivotal role in liver disease aggravation and virus replication. PC mutations (G1896A) and BCP double mutations (T1762/A1764) are important changes that alter expression of $\mathrm{HBeAg}$ [12], which is important for establishing viral persistence. Tong et al. reported that $42 \%$ of cirrhosis patients and $45 \%$ of HCC patients have the G1896A PC mutation, with the latter indicating a high risk of developing HCC [41]. Despite numerous related studies, the significance of this mutation remains obscure. According to our data, 32.5, 27.2, and $11.3 \%$ of the patients developed $\mathrm{BCP}, \mathrm{PC}$ and combined $\mathrm{BCP}$ and $\mathrm{PC}$ mutations, respectively. Only combined BCP and PC mutations was found to be negatively associated with the frequency of $\mathrm{CD} 4^{+}$ 
T cells IL- $17^{+}$. IL-17 can be contributed to the immune activation and disease aggravation in patients with chronic HBV infection, which might be related to viral persistence caused by HBV mutation, but there was few study on the relationship between IL-17 and HBV mutations, and it needs further studies. Within the feedback loop of Th1 and Th2 cytokines, IL-4 mediated Th2 cells differentiation and stability, thereby inhibiting cytokine production by Th1 cells [42, 43]. The associations observed in current study cohort confirmed a significantly positive and negative correlation between the frequency of $\mathrm{CD} 4^{+} \mathrm{T}$ cells $\mathrm{IL}-17^{+}$and presence of PC mutation as well as between the frequency of $\mathrm{CD} 4^{+} \mathrm{T}$ cells $\mathrm{IL}-10^{+}$ and $\mathrm{HBsAb}$ level, respectively. High IL-10 production was shown to be associated with greater ALT levels during the immune-clearance phase and greater rate of decrease in HBsAg titer, which were both key elements before spontaneous HBsAg seroconversion [44]. Opposite significant correlations of IL-10 between $\mathrm{HBsAg}$ and HBsAb in current study mainly showed the essential regulation response of $\mathrm{B}$ cell in the process for fighting against infections. We failed to identify significant associations between IL-10 and IL-17 secreted by CD4 ${ }^{+} \mathrm{T}$ cells in this treatment-naïve HBV cohort, suggesting that these two cytokines independently influence HBV antigen expression. These cells may interact during immune protection and immune inflammatory events throughout the disease phases of $\mathrm{CHB}$.

Genotype B is noted to associate with less severe liver disease and early spontaneous $\mathrm{HBeAg}$ seroconversion than non-genotype B HBV in both adults and children in Taiwan [11, 45]. IL-10 can inhibit formation of pro-inflammatory cytokines and correlated to anti-HBs response and $\mathrm{HBeAg}$ seroconversion [46, 47]. In our study, multivariate analysis demonstrated that IL-10 produced by $\mathrm{CD}^{+} \mathrm{T}$ cells was nearly positive correlated with genotype $\mathrm{B}$, not other genotypes, indicating that IL-10 produced by $\mathrm{CD}^{+} \mathrm{T}$ cells might play an important role in the pathogenesis of the less sever liver disease of genotype $\mathrm{B}$, and this need further study.

In conclusion, this study reveals that several components of the immune system are correlated with HBV factors that influence an inflammatory process during CHB. Of particular relevance are the significant associations between the frequency of $\mathrm{CD} 4^{+} \mathrm{T}$ cells $\mathrm{IL}-4^{+}$and quantitative HBsAg level, and between the frequency of $\mathrm{CD} 4^{+} \mathrm{T}$ cells $\mathrm{IL}-17^{+}$and the presence of PC mutation. The associations among the cytokines were independent from each other, even though significant relationships with one or more HBV markers were found. The limitation of this study was that data were gathered at a single point in time for each subject and analyzed by the linear regression model to identify the associations among clinical laboratory characteristics, virological information, and immunological parameters. Nonetheless, the results of this study highlight the importance of the host-virus relationship based on $\mathrm{T}$ cell effector or helper cytokines during immunity and immunopathology in $\mathrm{CHB}$.

\section{Conclusions}

Several components of the immune system are correlated to HBV factors that influence an inflammatory process during $\mathrm{CHB}$. Of particular relevance are the significant associations of between $\mathrm{CD} 4^{+} \mathrm{T}$ cells $\mathrm{IL}-4^{+}$and qHBsAg, and between $\mathrm{CD} 4^{+} \mathrm{T}$ cells $\mathrm{IL}-17^{+}$and the presence of $\mathrm{PC}$ mutation.

\section{Abbreviations \\ ALT: alanine aminotransferase; BCP: basal core promoter; $\mathrm{CHB}$ : chronic hepatitis B; GLB: globulin; GZ: gray zones; HBeAb: antibody to HBV e antigen; HBeAg: HBV e antigen; HBsAb: antibody to hepatitis B surface antigen; HBsAg: hepatitis B surface antigen; HBV: hepatitis B virus; HCC: hepatocellular carcinoma; IA: immune active; IC: inactive carrier; IFN- $\gamma$ : interferon- $\gamma$; IL: interleukin; IT: immune tolerant; PBMCs: peripheral blood mononuclear cells; PC: precore; Th: T helper}

\section{Acknowledgements Not applicable. \\ Funding \\ This study was supported in part by grants from the National Natural Science Foundation of China (81371866), International Cooperation Project of Guangzhou Science and Technology Program (2016201604030021), the National Grant Program on key Infectious Disease (2014ZX10002002-002). The funders had no role in the design of the study and collection, analysis, and interpretation of data and in writing the manuscript.}

\section{Availability of data and materials}

The datasets used and/or analysed during the current study are available from the corresponding author on reasonable request.

\section{Authors' contributions}

YG and $Y L$ contributed equally to this work. YG designed and performed experiments and drafted manuscript. YL performed experiments, analyzed data and generated Figs. LG designed experiments and analyzed data. LC designed experiments and provided help in ethics approval. XL designed and performed experiments. LZ collected samples and performed experiments. YLH performed experiments. JW performed experiments. YYH provided advice on study design, supervised project and analyzed data, provided critical review of manuscript. All authors have read and approved the final manuscript.

\section{Ethics approval and consent to participate}

Written informed consent was obtained from all patients. The study was approved by the Institutional Review Board of the Sun Yat-sen University and it conforms to the provisions of the Declaration of Helsinki.

\section{Consent for publication}

Not applicable.

\section{Competing interests}

The authors declare that they have no competing interests.

\section{Publisher's Note}

Springer Nature remains neutral with regard to jurisdictional claims in published maps and institutional affiliations. 
Received: 24 June 2017 Accepted: 26 February 2019

Published online: 04 March 2019

\section{References}

1. Ott JJ, Stevens GA, Groeger J, Wiersma ST. Global epidemiology of hepatitis $B$ virus infection: new estimates of age-specific HBsAg seroprevalence and endemicity. Vaccine. 2012;30(12):2212-9.

2. Trepo C, Chan HL, Lok A. Hepatitis B virus infection. Lancet. 2014;384 (9959): 2053-63.

3. Seeger C, Mason WS. Molecular biology of hepatitis B virus infection. Virology. 2015;479-480:672-86.

4. Geier A, Gartung C, Dietrich CG. Hepatitis B e antigen and the risk of hepatocellular carcinoma. N Engl J Med. 2002;347(21):1721-2; author reply 1721-1722.

5. Li X, Wang Y, Han D, Zhang W, Zhang Z, Ye X, Tian L, Dong Y, Zhu Q, Chen $Y$. Correlation of hepatitis $B$ surface antigen level with response to telbivudine in naive patients with chronic hepatitis B. Hepatol Res. 2014; 44(2):187-93.

6. Chan HL, Wong WW, Wong GL, Tse $\mathrm{CH}$, Chan HY, Sung JJ. A longitudinal study on the natural history of serum hepatitis B surface antigen changes in chronic hepatitis B. Hepatology. 2010;52(4):1232-41.

7. Nguyen T, Thompson AJ, Bowden S, Croagh C, Bell S, Desmond PV, Levy M, Locarnini SA. Hepatitis B surface antigen levels during the natural history of chronic hepatitis B: a perspective on Asia. J Hepatol. 2010;52(4):508-13.

8. Terrault NA, Bzowej NH, Chang KM, Hwang JP, Jonas MM, Murad MH. American Association for the Study of liver D: AASLD guidelines for treatment of chronic hepatitis B. Hepatology. 2016;63(1):261-83.

9. Fattovich G, Bortolotti F, Donato F. Natural history of chronic hepatitis B: special emphasis on disease progression and prognostic factors. J Hepatol. 2008:48(2):335-52.

10. Iloeje UH, Yang HI, Su J, Jen CL, You SL, Chen CJ. Risk evaluation of viral load E, associated liver disease/cancer-in HBVSG: predicting cirrhosis risk based on the level of circulating hepatitis B viral load. Gastroenterology. 2006;130(3):678-86.

11. Kao JH, Chen PJ, Lai MY, Chen DS. Hepatitis B genotypes correlate with clinical outcomes in patients with chronic hepatitis B. Gastroenterology. 2000;118(3):554-9.

12. Tong S, Revill P: Overview of hepatitis B viral replication and genetic variability. J Hepatol 2016, 64(1 Suppl):S4-16.

13. Huang Y, Lok AS: viral factors and outcomes of chronic HBV infection. Am J Gastroenterol 2011, 106(1):93-95.

14. Buster EH, Hansen BE, Lau GK, Piratvisuth T, Zeuzem S, Steyerberg EW, Janssen HL. Factors that predict response of patients with hepatitis B e antigen-positive chronic hepatitis B to peginterferon-alfa. Gastroenterology. 2009;137(6):2002-9.

15. Huang Y, Tai AW, Tong S, Lok AS. HBV core promoter mutations promote cellular proliferation through E2F1-mediated upregulation of S-phase kinase-associated protein 2 transcription. J Hepatol. 2013;58(6):1068-73.

16. Huang $Y$, Tong S, Tai AW, Hussain M, Lok AS. Hepatitis B virus core promoter mutations contribute to hepatocarcinogenesis by deregulating SKP2 and its target, p21. Gastroenterology. 2011;141(4):1412-21 1421 e1411-1415.

17. Rezende RE, Fonseca BA, Ramalho LN, Zucoloto S, Pinho JR, Bertolini DA, Martinelli AL. The precore mutation is associated with severity of liver damage in Brazilian patients with chronic hepatitis B. J Clin Virol. 2005;32(1):53-9.

18. Lapalus M, Laouenan C, Cardoso AC, Estrabaud E, Carvalho-Filho RJ, Zhang Q, Lada O, Appourchaux K, Mouri F, Boyer N, et al. Precore/Core promoter variants to predict significant fibrosis in both $\mathrm{HBeAg}$ positive and negative chronic hepatitis B. Liver Int. 2015;35(9):2082-9.

19. Bertoletti A, Wang FS. Overview of the special issue on HBV immunity. Cell Mol Immunol. 2015;12(3):253-4.

20. Rehermann B, Nascimbeni M. Immunology of hepatitis B virus and hepatitis C virus infection. Nat Rev Immunol. 2005;5(3):215-29.

21. Isogawa M, Tanaka Y. Immunobiology of hepatitis B virus infection. Hepatol Res. 2015;45(2):179-89.

22. Bertoletti A, Gehring A. Immune response and tolerance during chronic hepatitis B virus infection. Hepatol Res. 2007;37(Suppl 3):S331-8.

23. Takeuchi A, Badr Mel S, Miyauchi K, Ishihara C, Onishi R, Guo Z, Sasaki Y, Ike H, Takumi A, Tsuji NM, et al. CRTAM determines the CD4+ cytotoxic T lymphocyte lineage. J Exp Med. 2016;213(1):123-38.

24. Webster GJ, Reignat S, Brown D, Ogg GS, Jones L, Seneviratne SL, Williams R, Dusheiko G, Bertoletti A. Longitudinal analysis of CD8+ T cells specific for structural and nonstructural hepatitis B virus proteins in patients with chronic hepatitis B: implications for immunotherapy. J Virol. 2004;78(11): 5707-19.

25. Boni C, Laccabue D, Lampertico P, Giuberti T, Vigano M, Schivazappa S, Alfieri A, Pesci M, Gaeta GB, Brancaccio G, et al. Restored function of HBVspecific $T$ cells after long-term effective therapy with nucleos(t)ide analogues. Gastroenterology. 2012;143(4):963-973 e969.

26. Guidotti LG, Inverso D, Sironi L, Di Lucia P, Fioravanti J, Ganzer L, Fiocchi A, Vacca M, Aiolfi R, Sammicheli S, et al. Immunosurveillance of the liver by intravascular effector CD8(+) T cells. Cell. 2015;161(3):486-500.

27. Fletcher SP, Chin DJ, Ji Y, Iniguez AL, Taillon B, Swinney DC, Ravindran P, Cheng DT, Bitter H, Lopatin U, et al. Transcriptomic analysis of the woodchuck model of chronic hepatitis B. Hepatology. 2012;56(3):820-30.

28. Wherry EJ, Ha SJ, Kaech SM, Haining WN, Sarkar S, Kalia V, Subramaniam S, Blattman JN, Barber DL, Ahmed R. Molecular signature of CD8+ T cell exhaustion during chronic viral infection. Immunity. 2007;27(4):670-84.

29. Kao JH. Role of viral factors in the natural course and therapy of chronic hepatitis B. Hepatol Int. 2007;1(4):415-30.

30. Lindh M, Andersson AS, Gusdal A. Genotypes, nt 1858 variants, and geographic origin of hepatitis B virus--large-scale analysis using a new genotyping method. J Infect Dis. 1997;175(6):1285-93.

31. Chu CM, Liaw YF. HBsAg seroclearance in asymptomatic carriers of high endemic areas: appreciably high rates during a long-term follow-up. Hepatology. 2007;45(5):1187-92.

32. Liu J, Yang HI, Lee MH, Lu SN, Jen CL, Wang LY, You SL, Iloeje UH, Chen CJ. Group R-HS: incidence and determinants of spontaneous hepatitis B surface antigen seroclearance: a community-based follow-up study. Gastroenterology. 2010;139(2):474-82.

33. Tseng TC, Liu CJ, Su TH, Wang CC, Chen CL, Chen PJ, Chen DS, Kao JH: Serum hepatitis B surface antigen levels predict surface antigen loss in hepatitis B e antigen seroconverters. Gastroenterology 2011, 141(2):517-525, 525 e511-512.

34. Tseng TC, Liu CJ, Yang HC, Su TH, Wang CC, Chen CL, Kuo SF, Liu CH, Chen PJ, Chen DS, et al. Determinants of spontaneous surface antigen loss in hepatitis $B$ e antigen-negative patients with a low viral load. Hepatology. 2012;55(1):68-76.

35. Lee MH, Yang HI, Liu J, Batrla-Utermann R, Jen CL, Iloeje UH, Lu SN, You SL, Wang LY, Chen CJ, et al. Prediction models of long-term cirrhosis and hepatocellular carcinoma risk in chronic hepatitis B patients: risk scores integrating host and virus profiles. Hepatology. 2013;58(2):546-54.

36. Cui W, Sun CM, Deng BC, Liu P. Association of polymorphisms in the interleukin-4 gene with response to hepatitis $B$ vaccine and susceptibility to hepatitis B virus infection: a meta-analysis. Gene. 2013; 525(1):35-40.

37. Li M, Zhou ZH, Sun XH, Zhang X, Zhu XJ, Jin SG, Jiang Y, Gao YT, Li CZ, Gao $Y Q$. The dynamic changes of circulating invariant natural killer T cells during chronic hepatitis B virus infection. Hepatol Int. 2016;10(4):594-601.

38. Visvanathan K, Lewin SR. Immunopathogenesis: role of innate and adaptive immune responses. Semin Liver Dis. 2006;26(2):104-15.

39. Bertoletti A, Ferrari C: Adaptive immunity in HBV infection. J Hepatol 2016, 64(1 Suppl):S71-S83.

40. Chen W, Shi M, Shi F, Mao Y, Tang Z, Zhang B, Zhang H, Chen L, Chen L, Xin S, et al. HBcAg-pulsed dendritic cell vaccine induces Th1 polarization and production of hepatitis B virus-specific cytotoxic T lymphocytes. Hepatol Res. 2009;39(4):355-65.

41. Tong MJ, Blatt LM, Kao JH, Cheng JT, Corey WG. Precore/basal core promoter mutants and hepatitis B viral DNA levels as predictors for liver deaths and hepatocellular carcinoma. World J Gastroenterol. 2006; 12(41):6620-6.

42. Le Gros G, Ben-Sasson SZ, Seder R, Finkelman FD, Paul WE. Generation of interleukin 4 (IL-4)-producing cells in vivo and in vitro: IL-2 and IL-4 are required for in vitro generation of IL-4-producing cells. J Exp Med. 1990; 172(3):921-9.

43. Romagnani S. Regulation of the T cell response. Clin Exp Allergy. 2006; 36(11):1357-66

44. Wu JF, Hsu HY, Chiu YC, Chen HL, Ni YH, Chang MH. The effects of cytokines on spontaneous hepatitis B surface antigen seroconversion in chronic hepatitis B virus infection. J Immunol. 2015;194(2):690-6.

45. Ni YH, Chang MH, Wang KJ, Hsu HY, Chen HL, Kao JH, Yeh SH, Jeng YM, Tsai KS, Chen DS. Clinical relevance of hepatitis B virus genotype in children 
with chronic infection and hepatocellular carcinoma. Gastroenterology. 2004;127(6):1733-8.

46. Hohler T, Reuss E, Freitag CM, Schneider PM. A functional polymorphism in the IL-10 promoter influences the response after vaccination with $\mathrm{HBs} A g$ and hepatitis a. Hepatology. 2005;42(1):72-6.

47. Wu JF, Wu TC, Chen $\mathrm{CH}$, Ni YH, Chen HL, Hsu HY, Chang MH. Serum levels of interleukin-10 and interleukin-12 predict early, spontaneous hepatitis B virus e antigen seroconversion. Gastroenterology. 2010;138(1):165-172 e161-163.

Ready to submit your research? Choose BMC and benefit from:

- fast, convenient online submission

- thorough peer review by experienced researchers in your field

- rapid publication on acceptance

- support for research data, including large and complex data types

- gold Open Access which fosters wider collaboration and increased citations

- maximum visibility for your research: over $100 \mathrm{M}$ website views per year

At $\mathrm{BMC}$, research is always in progress.

Learn more biomedcentral.com/submissions 